\title{
Analysis of Relationship between Effectiveness of Internal Control System and Audit Opinions on Local Government Financial Statements
}

\author{
INDRA KESUMA \\ IRWAN TAUFIQ RITONGA* \\ Universitas Gadjah Mada
}

\begin{abstract}
This study aims to analyze and to describe the relationship between the effectiveness of the internal control system (ICS) and the audit opinion of the Audit Board (the AB) of the Republic of Indonesia on Local Government Financial Statements (LGFS). In addition, this study also aims to explain the consideration of ICS effectiveness in formulating audit opinion. This study uses an explanatory sequential mixed method. This study uses a different approach than previous research by considering materiality factors in assessing ICS's effectiveness. The sample of this study is fifty-four AB Audit Reports on LGFS in Indonesia. Analytical tools used include content analysis, correlation analysis, mean difference tests, and textual data analysis. Content analysis is performed on fifty-four ICS Audit Reports year 2017, correlation analysis utilizes Somer's $d$ and Kendall's tau c, and mean difference test analysis uses Kruskal Wallis. Meanwhile, textual data analysis is carried out on interviews with nine auditors from three $A B$ representative offices in Java. This study shows that ICS's effectiveness has a strong and positive relationship with an audit opinion on LGFS. In addition, the average score of ICS effectiveness is different for each group of LGFS audit opinions. This fact shows that AB has considered ICS effectiveness in formulating audit opinions. The interview results show that the relationship between the effectiveness of ICS and audit opinion is indirect. The AB considers the effectiveness of ICS in the phase of determining audit planning materiality rate and in the phase of analyzing the impact of ICS findings on the fairness of LGFS. This result implies that the government should revise audit regulations by removing ICS effectiveness as one factor that must be considered in the formulation of audit opinion because ICS effectiveness and audit opinion are not directly related.
\end{abstract}

Keywords: Internal Control System, Local Government, Audit Opinion, Financial Statements

Abstrak: Penelitian ini bertujuan untuk menganalisis dan mendeskripsikan hubungan antara efektivitas sistem pengendalian internal (SPI) dan opini audit Badan Pemeriksa Keuangan Republik Indonesia (BPK RI) terhadap Laporan Keuangan Pemerintah Daerah (LKPD). Selain itu, penelitian ini juga bertujuan untuk menjelaskan pertimbangan efektivitas SPI dalam proses merumuskan opini audit. Penelitian ini menggunakan metode campuran sekuensial penjelasan. Penelitian ini menggunakan pendekatan yang berbeda dibandingkan dengan penelitian sebelumnya dengan 
mempertimbangkan faktor materialitas dalam menilai efektivitas SPI. Sampel penelitian ini adalah lima puluh empat laporan hasil pemeriksaan atas laporan keuangan pemerintah daerah di Indonesia. Alat analitik yang digunakan meliputi analisis isi, analisis korelasi, uji perbedaan rata-rata, dan analisis data tekstual. Analisis isi dilakukan pada lima puluh empat Laporan Pemeriksaan SPI tahun 2017, analisis korelasi menggunakan Somer's d dan Kendall's tau c, dan analisis uji beda rata-rata menggunakan Kruskal Wallis. Sementara itu, analisis data tekstual dilakukan pada hasil wawancara dengan sembilan auditor dari tiga kantor perwakilan BPK di Jawa. Hasil penelitian ini menunjukkan bahwa efektivitas SPI memiliki hubungan yang kuat dan positif dengan opini audit. Selain itu, skor rata-rata efektivitas SPI berbeda untuk setiap kelompok opini audit. Fakta ini menunjukkan bahwa BPK telah mempertimbangkan efektivitas SPI dalam merumuskan opini audit. Hasil wawancara menunjukkan bahwa pola hubungan antara efektivitas ICS dan opini audit adalah tidak langsung. BPK mempertimbangkan efektivitas SPI dalam fase penentuan tingkat materialitas perencanaan audit dan dalam tahap menganalisis dampak temuan SPI pada kewajaran LKPD. Implikasi dari hasil penelitian ini adalah bahwa pemerintah sebaiknya merevisi regulasi pemeriksaan keuangan dengan menghilangkan efektivitas SPI sebagai salah satu faktor yang harus dipertimbangkan dalam perumusan opini audit karena efektivitas SPI dan opini audit tidak berhubungan langsung.

Kata Kunci: Sistem Pengendalian Internal, Pemerintah Daerah, Opini Audit, Laporan Keuangan

\section{Introduction}

To support the realization of good governance in the state administration, state finance must be managed professionally, openly, and responsibly. To achieve this, state finance must be managed by paying attention to general principles such as resultsoriented accountability, professionalism, proportionality, openness, and financial audit by free and independent examining bodies.

State finances audit includes examining the management of state finances and responsibility of state finances. The constitution mandates the task to the Audit Board of the Republic of Indonesia (the AB of RI) (Republik Indonesia, 1945). To carry out the constitutional duties, the $\mathrm{AB}$ of $\mathrm{RI}$ is given authorities to conduct three types of audits: financial audit, performance audit, and audit with specific objectives (Republik Indonesia, 2004). 
A financial audit is an audit of government financial statements. This audit is intended to provide an opinion statement about the fairness of the information presented in the government's financial statements (Republik Indonesia, 2004). There are four types of opinions that can be given on government financial statements, namely Unqualified Opinion, Qualified Opinion, Adverse Opinion, and Disclaimer Opinion (Badan Pemeriksa Keuangan, 2014).

The audit opinion is the auditor's professional statement regarding the fairness of financial information presented in financial statements based on these criteria: (1) conformity with government accounting standards, (2) adequacy of disclosures, (3) compliance with laws and regulations, and (4) effectiveness of the ICS (Republik Indonesia, 2004). The four criteria are accumulative so that they must be considered entirely in the formulation of opinions, including ICS's effectiveness. Therefore, the auditor must carry out testing and evaluate the implementation of government ICS when doing a financial audit (the Republic of Indonesia, 2004). In addition, the 2017 State Financial Audit Standards also requires the AB of RI to prepare three types of audit report, namely (1) Audit Report for Financial Statements, (2) Audit Report for ICS, and (3) Audit Report for Compliance with Laws and Regulations.

Based on the description above, it can be concluded that ICS's effectiveness is one of the essential criteria in formulating audit opinion. The more effective the internal control system, the better the audit opinion of the financial statements obtained. The reliability of financial statements is a function of internal control effectiveness (Li et al., 2012). In the context of financial reporting, effective ICS can prevent or detect and correct material misstatements on time (Ikatan Akuntan Publik Indonesia, 2013) because ICS is intended to provide sufficient confidence in the achievement of organizational goals through effective and efficient activities, reliability of financial reporting, the security of state assets, and compliance with laws and regulations (the Republic of Indonesia, 2008). Conversely, an ineffective ICS may result in incomplete accounting records and/or inadequate available documents and/or the system does not produce valid accounting data. 
Previous researchers have analyzed the relationship between ICS and audit opinion of local government financial statements (LGFS). They state that number of audit findings on ICS has a significant effect on the audit opinion of LGFS (Kusumawati and Ratmono, 2017; Widodo and Sudarno, 2017; Munawar, 2016; Fatimah et al., 2014). An increasing number of weaknesses in the ICS also contributed to a decline in an audit opinion of LGFS (Kawedar, 2010). Those results are supported by Ningsih (2016) study, which states that the most frequent factor that causes qualifications of accounts of LGFS is the ICS weakness.

However, different results are concluded by Safitri and Darsono (2015). Using the Audit Report of LGFS 2010-2012 in Java, they conclude that the ICS's weakness does not significantly influence the AB's audit opinion. Suwanda (2015) also states that the implementation of ICS does not significantly influence the quality of LGFS.

Based on previous research, it can be seen that there are still differences in conclusions regarding the relationship between the effectiveness of ICS and audit opinions on LGFS. Some studies (see Kusumawati and Ratmono, 2017; Widodo and Sudarno, 2017; Munawar 2016; Fatimah et al. 2014, Kawedar 2010, Ningsih, 2016) state that ICS effectiveness has a significant effect on audit opinion of LGFS and other studies (see Safitri and Darsono, 2016; Suwanda 2015) state otherwise. Those studies mentioned above only use several internal control findings as a proxy for ICS weakness and ignore the concept of audit materiality. In fact, in determining audit opinion, the auditor considers the state financial audit standards, level of conformity, adequacy of financial statement disclosures associated with determining materiality level, entity's response to results of the audit, and the representation letter (Badan Pemeriksa Keuangan, 2014). Therefore, this study aims to confirm the relationship between ICS and audit opinion on LGFS by improving the ICS effectiveness assessment method. In addition, this study also analyzes how ICS's effectiveness is considered in the formulation of the audit opinion. This study shows that the effectiveness of ICS has a strong and positive relationship with an audit opinion on LGFS. Besides, this study concludes that ICS affects audit opinion indirectly by determining the rate of planning materiality of financial statements. 
This study contributes by improving the measurement of ICS effectiveness by considering the number of ICS findings and considering the materiality of the amount of the findings. This is because the materiality of the ICS findings amount is one of the variables considered in the formulation of the audit opinion. Another contribution of this study is to provide a framework of argumentation about the relationship between ICS and audit opinion that has been difficult to find in previous studies. In practical terms, this study's results contribute to the $\mathrm{AB}$ in terms of policy-making in the formulation of the audit opinion, particularly the consideration of the effectiveness of ICS in the formulation of the audit opinion.

\section{Literature Review and Hypothesis Development}

\subsection{Internal Control System (ICS)}

The Internal Control System is an integral process for actions and activities carried out continuously by the leaders and all employees to provide adequate assurance of organizational goals through effective and efficient activities, reliability of financial reporting, safeguarding state assets, and compliance with laws and regulations. ICS consists of the control environment, risk assessment, control activities, information and communication, and internal control monitoring (Republik Indonesia, 2008).

Auditors of the $\mathrm{AB}$ must obtain an adequate understanding of the internal control system relevant both in terms of time and substance to the audit or material nature of the subject matter (Republik Indonesia, 2017a). In financial audits, relevant controls may relate to financial reporting, but not all financial reporting controls are relevant to audits (Ikatan Akuntan Publik Indonesia, 2013). In various literature such as Statement on Auditing Standards (SAS) 130 (American Institute of Certified Public Accountant 2015) and Auditing Standard 5 (Public Company Accounting Oversight Board, 2007), this internal control is known as internal control over financial reporting (ICFR). ICFR is an ICS specifically designed to provide adequate assurance that the financial statements produced are reliable, reported, and prepared following government accounting standards. 


\subsection{Effectiveness of ICS}

Republic Indonesia (2017b) divides ICS's effectiveness on financial reporting into three-level, namely effective, effective with exceptions, and contains material weaknesses. ICS is effective if there are no significant deficiencies and material weaknesses. ICS is effective with exceptions if there are significant deficiencies that do not result in material weakness if combined. Meanwhile, ICS contains material weaknesses if there are one or more material weaknesses, or there is a combination of significant deficiencies that result in material weaknesses.

For research purposes, referring to Republic Indonesia (2017b), ICS containing material weaknesses is further classified into three-level, namely ICS with (1) contains material weaknesses and are not pervasive, i.e., if existing material weaknesses do not have a broad impact on financial statements; (2) contains material and pervasive weaknesses, i.e., if existing material weaknesses have a broad impact on financial statements; and (3) contains material, pervasive, and limiting weaknesses, i.e., if there are restrictions on the scope of the audit and possible effects on financial statements are material and pervasive.

\subsection{Audit Opinion on LGFS}

There are four types of opinions that can be given on government financial statements, namely Unqualified Opinion, Qualified Opinion, Adverse Opinion, and Disclaimer Opinion (Badan Pemeriksa Keuangan, 2014). Based on ISSAI 4706 in the LGFS Guidelines 2016, there is an additional form of communication in the auditor's report in the form of an Emphasis on Matter Paragraphs and the Other Matter Paragraphs. The emphasis of Matter Paragraphs is included in the auditor's report if the auditor has obtained sufficient and appropriate audit evidence that there is no material misstatement of the matter in the financial statements. According to Practice Note ISSAI 1706, one example of the relevant conditions to be included in the Emphasis of Matter Paragraphs is a significant internal control deficiency. Thus, local governments whose LGFSs are fairly presented following Government Accounting Standards but have significant ICS deficiency findings can be given Unqualified Opinion with Emphasis on Matter Paragraphs. 


\subsection{Relationship between Effectiveness ICS and Audit Opinion}

Various regulations and references regarding auditing do not explicitly explain the relationship between the effectiveness of ICS and the audit opinion on LGFS. What is always explained explicitly is the relationship between the effectiveness of ICS and the audit strategy. However, this study provides arguments about the relationship between the effectiveness of ICS and audit opinion on LGFS.

According to the Republic of Indonesia (2008), the purpose of ICS is to provide adequate confidence in achieving organizational goals through effective and efficient activities, reliability of financial reporting, safeguarding state assets, and compliance with laws and regulations. Thus, in the context of financial reporting, effective ICS is ICS, which, either individually or together with other controls, can prevent or detect and correct material misstatements promptly (Ikatan Akuntan Publik Indonesia, 2013). An ineffective ICS may result in incomplete accounting records and/or inadequate available documents and/or the system does not produce valid accounting data. These three conditions are conditions that do not allow the auditor to carry out an adequate audit procedure, which may result in the auditor giving a "qualified opinion" due to scope limitations (if material but not pervasive) or "disclaimer opinion" (if material and pervasive) (BPK 2016). The relationship between ICS effectiveness and audit opinion is evident in the provision of an audit opinion on government financial statements, which states that the formulation of an audit opinion is carried out by considering, among other things, the reliability of ICS.

If ICS's effectiveness is at the level of "effective" or "effective with the exception", management declares that the financial statements have been prepared based on adequate ICS. In ICS with an "effective with exception" level, management will state that their ICS is adequate because there are no material weaknesses found. However, if ICS's effectiveness is at the level of "containing material weaknesses", management cannot declare that their ICS is adequate (Republik Indonesia, 2017b). Based on the description, the possible relationship between the level of effectiveness of ICS and audit opinion on LGFS is as follows. 
Table 1.

Possible Relationship between ICS Level and Audit Opinion

\begin{tabular}{cll}
\hline No. & ICS Effectiveness Level & \multicolumn{1}{c}{ Possible Audit Opinions } \\
\hline 1 & Effective & $\begin{array}{l}\text { Unqualified Opinion } \\
\text { Unqualified Opinion with a Paragraph } \\
\text { Emphasis on Matter } \\
\text { Qualified Opinion }\end{array}$ \\
3 & $\begin{array}{l}\text { Contains Material Weakness, Not with Exceptions } \\
\text { Pervasive } \\
\text { Contains Material Weaknesses and Adverse Opinion } \\
\text { Pervasive } \\
\text { Contains Material Weaknesses, Disclaimer Opinion } \\
\text { Pervasive and Scope Restrictions }\end{array}$ \\
\hline
\end{tabular}

Table 1 shows that the worse the ICS condition, the worse the audit opinion on LGFS is. This is because effective ICS will minimize the possibility of misstatements in the financial statements. Based on this explanation, we propose an alternative hypothesis as follows.

Ha: There is a significant and positive relationship between the effectiveness of ICS and the audit opinion on LGFS.

\section{Research Method}

This study used an explanatory sequential mixed method. With this method, authors first conduct quantitative research, analyzed the results, and then arrange the results to explain them in more detail with qualitative research (Creswell, 2016).

This study is carried out through three stages. Firstly, the authors assess the level of ICS effectiveness by analyzing and assessing the level of the weakness of ICS findings in the $\mathrm{AB}$ Audit Reports based on five criteria stipulated in Minister of Finance Regulation No. 14/PMK.09/2017. Secondly, the authors use correlation analysis to assess the relationship between ICS and LGFS opinion's effectiveness. A mean difference test analysis strengthens correlation analysis. Thirdly, the authors interview to determine how the auditors undertake the process of understanding ICS and ICS testing and how auditors consider ICS in the formulation of audit opinion on LGFS. 


\subsection{Population and Samples}

The population of this study is $542 \mathrm{AB}$ Audit Reports on LGFS, according to the number of local governments in Indonesia. The sample chosen is fifty-four AB Audit Reports on LGFS consisting of eighteen reports with Unqualified Opinion, eighteen reports with Qualified Opinion, and eighteen reports with Disclaimer Opinion. The selection of eighteen samples per type of audit opinion is carried out because the smallest number of multiples of the three types of audit opinion is eighteen, namely LGFS, with a disclaimer opinion. Based on the 2018 Semester I Audit Results Summary Report, no LGFS received an adverse opinion.

\subsection{Data and Data Collection Technique}

This study uses both primary and secondary data. The secondary data is the LGFS containing in the $\mathrm{AB}$ report for the fiscal year 2017. This data is collected directly from the $\mathrm{AB}$. The primary data is interview data collected by in-depth interviews with nine auditors with roles as Team Leader, Technical Controller, or Responsible Agency for the AB Representatives in Jawa Tengah Province, the AB Representatives in Jawa Timur Province, and the AB Representatives in Daerah Istimewa Yogyakarta Province. Interviews are conducted in a semi-structured manner using interview questions.

\subsection{Operational Definition of Variables}

The variables in this study are the effectiveness of ICS and audit opinions on LGFS. The ICS effectiveness variables are categorized into an ordinal scale, namely effective $=1$, effective with exceptions $=2$, containing material weaknesses, not pervasive $=3$, containing material and pervasive weaknesses $=4$, and containing material weaknesses and scope restrictions $=5$. Effectiveness internal control is obtained from analyzing the level of internal control deficiencies reported to the $\mathrm{AB}$ Audit Report on the internal control system.

The audit opinion on LGFS variables are also categorized in the form of an ordinal scale and sorted according to the order of opinion quality from the best to the worst (Badan Pemeriksa Keuangan, 2014), namely unqualified opinion $=1$, unqualified opinion with paragraphs emphasizing a matter $=2$, qualified opinion $=3$, adverse opinion $=4$, and disclaimer opinion $=5$. 


\subsection{Data Analysis Technique}

This study's analytical tools include content analysis, correlation analysis, mean difference tests, and textual data analysis. The effectiveness of internal control is measured by scoring techniques based on the ICS effectiveness criteria for financial reporting, as stipulated in Minister of Finance Regulation No. 14/PMK.09/2017. The relationship between the effectiveness of ICS and opinion is measured by using Somer's d correlation analysis and Kendall's tau c. Mean different tests are carried out using Kruskal Wallis. Meanwhile, to explain how ICS's effectiveness is considered in the formulation of audit opinions is obtained from textual data analysis of interview results with AB Auditors.

In more detail, content analysis is carried out in the following stages: (1) understanding and reviewing the AB Audit Report for ICS, (2) analyzing the level of ICS weakness by considering factors F1 to F5, (3) preparing a working paper evaluating the findings of the ICS in the following format.

Table 2.

Working Paper of ICS Findings Assessment

\begin{tabular}{|c|c|c|c|c|c|c|c|}
\hline \multirow{2}{*}{ No } & \multirow{2}{*}{$\begin{array}{l}\text { Description } \\
\text { of Findings }\end{array}$} & \multicolumn{4}{|c|}{ Consideration Factors } & \multirow{2}{*}{ Average } & \multirow{2}{*}{$\begin{array}{l}\text { Level of } \\
\text { Findings } \\
\end{array}$} \\
\hline & & $\begin{array}{ll}\text { F1 } & \text { F2 } \\
\end{array}$ & F3 & F4 & F5 & & \\
\hline \multicolumn{8}{|l|}{1} \\
\hline \multicolumn{8}{|l|}{2} \\
\hline$\ldots$ & & & & & & & \\
\hline $\mathrm{n}$ & & & & & & & \\
\hline
\end{tabular}

Details of considering factors "F1" to "F5" are "F1" is indicating fraud, "F2" is the level of subjective judgment and complexity in determining account values, "F3" is possible deficiencies repeatedly occur, "F4" is the size of the account balance includes the magnitude of the finding value relative to the account balance. The affected transactions and the assertions of the financial statements involved, and "F5" is ICS entity level findings that significantly affect the financial statements.

A column of "F1" up to "F5" is filled with number "1" if it is low, "2" if it is medium, and "3" if it is high. Factors of "F1" to "F5" have a similar weight rating. 
Column "Level of Findings" is filled with "inconsequential" if the value in the "Average" column is 1.0 to 1.5 ; "significant deficiency" if the value in the "Average" column is $>1.5$ to 2.5 ; and "material weakness" if the value in the "Average" column is $>2.5$ to 3.0 .

The conclusion of the effectiveness of ICS as a whole is categorized as "ICS is effective" if there are no significant deficiencies and material weaknesses; "ICS is effective with exceptions" if there is one or more significant deficiencies which, when combined, do not result in material weaknesses; "ICS contains material weaknesses and is not pervasive" if there are one or more material weaknesses or there is a combination of significant deficiencies that result in material weaknesses but are not pervasive; "ICS contains material weaknesses and pervasive" if there are one or more material weaknesses or there is a combination of significant deficiencies that result in material weaknesses and are pervasive to the entire financial statement; and "ICS contains material weaknesses, pervasive, and scope limitations" if there are one or more material weaknesses or there is a combination of significant deficiencies that result in material weaknesses are pervasive and there are limitations scope so the auditor cannot obtain sufficient and adequate evidence.

\section{Results and Discussion}

\subsection{Level of Findings of ICS Weaknesses}

There are a total of 419 ICS weaknesses findings from fifty-four Audit Reports. Results of the analysis of those ICS findings show that $67.30 \%$ of the findings are at the level of significant deficiency, and $25.06 \%$ of the findings are at the level of material weakness. Meanwhile, only $7.64 \%$ of the findings are at the inconsequential level.

If detailed by type of audit opinion, material weakness findings are increasing directly proportional to the worsening audit opinion on LGFS. The proportion of each level of ICS weakness findings per type of opinion can be seen in Table 3.

An increase in the proportion of material weakness findings that are in line with the decline in the quality of audit opinions indicates that the ICS's effectiveness is considered in the formulation of audit opinion on LGFS. This is because the worse the 
ICS's condition (marked by an increase in material weakness findings), the worse the audit opinion will be.

Table 3.

The proportion of Level of Findings of ICS Weaknesses per LGFS Audit Opinion

\begin{tabular}{clccc}
\hline No & Audit Opinion & Inconsequential & $\begin{array}{c}\text { Significant } \\
\text { Deficiency }\end{array}$ & $\begin{array}{c}\text { Material } \\
\text { Weakness }\end{array}$ \\
\hline 1 & Unqualified & $11,96 \%$ & $86,92 \%$ & $1,12 \%$ \\
\hline 2 & Qualified & $6,63 \%$ & $70,45 \%$ & $22,92 \%$ \\
\hline 3 & Disclaimer & $3,52 \%$ & $50,88 \%$ & $45,60 \%$ \\
\hline
\end{tabular}

Details of the level of the weakness of ICS per local government can be seen in appendix 1 .

\subsection{Level of ICS Effectiveness}

Results show that no local government has an effective ICS. There are a significant portion of local governments (20 out of 54) that has ICS with levels containing material weaknesses but not pervasive. The details of the effectiveness of ICS per opinion can be seen in Table 4.

Table 4.

Level of ICS Effectiveness per LGFS Audit Opinion

\begin{tabular}{cccccc}
\hline No & Opinion & $\begin{array}{c}\text { Effective } \\
\text { with } \\
\text { Exceptions }\end{array}$ & $\begin{array}{c}\text { Contains Material } \\
\text { Weakness, Not } \\
\text { Pervasive }\end{array}$ & $\begin{array}{c}\text { Contains Material } \\
\text { Weakness, Pervasive, } \\
\text { Scope Limitation }\end{array}$ & Total \\
\hline 1 & Unqualified & 16 & 2 & - & 18 \\
\hline 2 & Qualified & - & 18 & - & 18 \\
\hline 3 & Disclaimer & - & - & 18 & 18 \\
\hline & Total & 16 & 20 & 18 & 54 \\
\hline
\end{tabular}

Details of the effectiveness of ICS per local government can be seen in Appendix 2. Table 4 above shows that all local governments with Qualified and Disclaimer Opinions have ICS at the level of "containing material weaknesses but not pervasive" and "containing material weaknesses, pervasive, and scope restrictions". This situation is as expected. However, the unexpected result is that there are two local governments with unqualified opinions but still have ICS containing material weaknesses. Although 
the amount is only small ( 2 of 16 or about $12.5 \%$ ), from the point of view of the compliance presentation framework, this condition shows the potential of incorrect opinion on the financial statements. This condition indicates that the auditors may not consider ICS's effectiveness in the formulation of the audit opinion, as stated in the auditing standards for state finances.

However, when viewed from the lens of the fairness presentation framework, ICS containing material weaknesses does not necessarily result in a material misstatement of financial statements. In the two cases above, the auditors have likely modified their audit strategies following the existing ICS effectiveness conditions and conclude that there were no material misstatements found in the two LGFSs.

\subsection{Relationship between Effectiveness of ICS and Audit Opinion}

For statistical analysis, the level of ICS effectiveness and LGFS audit opinions are transformed into an ordinal scale, as explained in section 3.3. Operational Definition of Variables above.

Next, Somer's d and Kendall's tau c correlation analyzes are performed to analyze the correlation between ICS effectiveness and audit opinion. Kendall's tau c and Somer's $\mathrm{d}$ are used because the research variables are from the same object, and there are lots of data with the same rank. The results of the correlation analysis can be seen in Table 5 and Table 6.

Table 5.

Somer's d Test Results

\begin{tabular}{lcccc}
\hline \multicolumn{1}{c}{ Description } & Value & $\begin{array}{c}\text { Asymptotic } \\
\text { Standardized Error }\end{array}$ & $\begin{array}{c}\text { Approximate } \\
T\end{array}$ & $\begin{array}{c}\text { Approximate } \\
\text { Significance }\end{array}$ \\
\hline Symmetric & 0,965 & 0,024 & 37,470 & 0,000 \\
\hline $\begin{array}{l}\text { ICS Effectiveness_ } \\
\text { Dependent }\end{array}$ & 0,963 & 0,026 & 37,470 & 0,000 \\
\hline Opinion_Dependent & 0,967 & 0,023 & 37,470 & 0,000 \\
\hline
\end{tabular}

Table 6.

Kendall's tau c Test Results

\begin{tabular}{cccc}
\hline Value & Asymptotic & $\begin{array}{c}\text { Approximate } \\
T\end{array}$ & $\begin{array}{c}\text { Approximate } \\
\text { Significance }\end{array}$ \\
\hline 0,963 & 0,026 & 37,470 & 0 \\
\hline
\end{tabular}


The Somer's d test results for the conclusion are the correlation values with audit opinion variables as dependent variables. The significance value of Somer's $d$ and Kendall's tau c is smaller than $5 \%$ so that the measurement results are statistically significant. That is, the effectiveness of ICS and audit opinion is significantly correlated.

The two measurements' correlation coefficient values ( 0.967 for Somer's $d$ and 0.963 for Kendall's tau c) show a robust correlation between the two variables. The effectiveness of ICS and audit opinion correlates significantly and positively. This means that the more effective an ICS, the better the audit opinion.

To strengthen the correlation analysis, the two variables are tested again using the Kruskal Wallis test. The initial step of testing is performed by changing both variables' ordinal scale into an interval scale. The changing scale is carried out using the "method of successive interval (MSI)" technique. Kruskal Wallis test results can be seen in Table 7.

Table 7.

Kruskal Wallis Test Results

\begin{tabular}{|c|c|c|c|}
\hline & Opinion & $\mathrm{N}$ & Mean Rank \\
\hline \multirow[t]{5}{*}{ ICS } & 1,00 & 18 & 10,50 \\
\hline & 2,00 & 18 & 26,50 \\
\hline & 3,00 & 18 & 45,50 \\
\hline & Total & 54 & \\
\hline & \multicolumn{2}{|c|}{ Asymp. Sig. } & 0,000 \\
\hline
\end{tabular}

The significance of the Kruskal Wallis test results above is less than 5\%. Therefore, it can be concluded confidently that there are differences in the mean values of ICS effectiveness for each audit opinion group.

The correlation analysis results and mean difference tests above show a significant and positive relationship between ICS effectiveness and LGFS audit opinion. These indicate that the effectiveness of ICS has been considered in the formulation of audit opinions. Thus, the alternative hypothesis proposed in this study is accepted. The results of this study confirm previous studies which state that ICS effectiveness has a significant effect on audit opinion of LGFS (see Kusumawati and Ratmono, 2017; Widodo and Sudarno, 2017; Munawar 2016; Fatimah et al. 2014, Kawedar 2010, 
Ningsih, 2016). This study also proves that the compliance presentation framework applies to the formulation of audit opinions on local government financial reports. The effectiveness of ICS, which has been conceptualized to determine the audit strategy in auditing business organizations, is considered to formulate audit opinions in local government organizations. This shows that giving an audit opinion on the LGFS considers the presence or absence of material misstatements in the financial statements and considers the appropriateness of carrying out organizational activities. This fact demonstrates that the audit of government organizations is different from the audit of business organizations.

\subsection{The Consideration of ICS Effectiveness in Formulating Audit Opinion}

How is the effectiveness of ICS considered in the formulation of opinion? These problems were answered by conducting interviews with nine auditors at the $A B$ Representative at Jawa Tengah Province, the $\mathrm{AB}$ Representative at Jawa Timur Province, and the AB Representative at Daerah Istimewa Yogyakarta Province. The three representatives were chosen to consider ease of access and lower research costs compared to sampling at other representatives without disrupting the quality of the study.

The interview results show that auditors conclude the effectiveness of the ICS from the COSO questionnaire At the time of the preliminary audit. This conclusion is used as one criterion in determining the audit planning materiality (PM) rate. PM rate is a measure of materiality that will be used to assess whether a misstatement in the LGFS affects audit opinion or not. The PM rate is then multiplied by the total expenditure to obtain the PM value. The conclusion is obtained based on the following interview excerpt.

\section{"Yes. For the LGFS examination, the percentage of materiality level used to determine PM based on entity-level risk consists of 6 elements, one of which is the effectiveness of ICS."}

\footnotetext{
3. The COSO questionnaire is a series of questions to answer the fulfillment of five components of internal control within the government.
} 
On the other hand, ICS's findings are quantified to a nominal impact on financial statements' fairness. The impact of these findings can be in the form of misstatements or scope restrictions. Then, the impact of the ICS's weaknesses is compared with the PM values previously obtained to determine opinions on LGFS. If the impact is not material (less than 50\% of PM), the opinion is an Unqualified Opinion. If the impact is material but not pervasive, the opinion is Qualified Opinion. Whereas if the impact is material and pervasive, adverse or disclaimer's opinion depends on whether or not limitations to the scope therein.

Interview results indicate that the ICS's effectiveness is not used directly in the formulation of audit opinions. Auditors use ICS's effectiveness as one of the components determining the rate of planning materiality (PM) and the determinants of substantive inspection strategies to ascertain whether misstatements caused by ICS weaknesses occur. PM is a measure of materiality that will be used to assess whether a misstatement in the LGFS affects the audit opinion or not. The more effective the ICS, the higher the PM value so that the financial statements' materiality limit will increase. On the other hand, the determination of the audit opinion on LGFS is carried out based on the accumulated analysis of the value of the findings relating to ICS compared to the financial statements' materiality value. With the increase in the materiality limit of financial statements (i.e., effective ICS and high PM), the probability of getting an unqualified opinion will increase. Thus, the relationship between the effectiveness of ICS and audit opinions on LGFS is indirect. Among the interview excerpts showing this are as follows.

"Cannot be connected directly because it is a device for determining PM, then when the opinion was included there ... When there was a finding of its value ... eee ... the quantitative was there, or the impact could be calculated ... if it was above half a PM then it will definitely hit ... If half a PM hit means the ICS already counted there. How much PM is it? That's the formula from the ICS. So there are findings above half a PM that means it's already severe ..." 


\section{Conclusion, Limitation, and Implication}

\subsection{Conclusion}

Correlation analysis results show that ICS's effectiveness and audit opinion on LGFS have a strong and positive relationship. In addition, the analysis of mean difference tests also showed that the average value of the effectiveness of ICS is different for each level of LGFS audit opinion. This means that the ICS conditions for local governments with Unqualified Opinions will differ from the ICS condition of local governments with Qualified Opinions, Adverse, or Disclaimer Opinions. These two facts show that ICS's effectiveness correlates with LGFS audit opinion and has been considered by the $\mathrm{AB}$ in the audit opinion formulation process.

The interview results explained that the pattern of the relationship between ICS effectiveness and audit opinion is indirect. The effectiveness of ICS is considered when determining audit planning materiality (PM) and when quantifying the impact of ICS weaknesses on the fairness of financial statements.

\subsection{Limitation and Implication}

This study has several limitations. First, this study only used fifty-four Audit Reports and three $\mathrm{AB}$ representative offices as research samples based on purposive sampling. Therefore, the results of this study cannot be generalized to other $\mathrm{AB}$ representative offices. Second, this study does not analyze audit working paper documents to describe the process of understanding and testing the ICS so that the triangulation of techniques cannot be done to validate the results of interviews. Third, this study does not include intervening variables in measuring the correlation between ICS effectiveness and audit opinion on LGFS

The indirect relationship between ICS effectiveness and audit opinion shows that ICS should not be one of the criteria in formulating audit opinion. Conclusions about the level of ICS effectiveness are used to determine audit strategy, not the audit opinion. Therefore the government should revise regulations, such as the State Financial Audit Act and State Financial Audit Standards, which state that ICS is one factor that must be considered in the formulation of the audit opinion. 


\section{References}

American Institute of CPAs. 2015. AU-C Section 940 An Audit of Internal Control Over Financial Reporting That Is Integrated With an Audit of Financial Statements.

Badan Pemeriksa Keuangan. 2014. Keputusan Badan Pemeriksa Keuangan Republik Indonesia Nomor 4/K/I-XIII.2/7/2014 tentang Petunjuk Pelaksanaan Pemeriksaan Keuangan. Jakarta

Badan Pemeriksa Keuangan. 2016. Keputusan Badan Pemeriksa Keuangan Republik Indonesia Nomor 3/K/I-XIII.2/3/2016 tentang Buku Panduan Pemeriksaan Laporan Keuangan Pemerintah Daerah. Jakarta

Badan Pemeriksa Keuangan. 2018. Ikhtisar Hasil Pemeriksaan Semester I Tahun 2018. Jakarta: Badan Pemeriksa Keuangan.

Creswell, J.W.. 2016. Research Design: Pendekatan Metode Kualitatif, Kuantitatif, dan Campuran. Edisi Keempat. Yogyakarta: Pustaka Pelajar.

Fatimah, Desi., R.N. Sari, and M. Rasuli. 2014. "Pengaruh Sistem Pengendalian Intern, Kepatuhan Terhadap Peraturan Perundang-undangan, Opini Audit Tahun Sebelumnya dan Umur Pemerintah Daerah Terhadap Penerimaan Opini WTP pada LKPD Seluruh Indonesia.” Jurnal Akuntansi: Media Riset Akuntansi \& Keuangan, Vol. 3, No. 1.

Ikatan Akuntan Publik Indonesia. 2013. Standar Audit 315 Pengidentifikasian dan Penilaian Risiko Kesalahan Penyajian Material Melalui Pemahaman atas Entitas dan Lingkungannya. Jakarta: Ikatan Akuntan Publik Indonesia.

Kawedar, Warsito. 2009. "Opini Audit dan Sistem Pengendalian Intern (Studi Kasus di Kabupaten PWJ yang Mengalami Penurunan Audit)" Jurnal Akuntansi dan Auditing Universitas Diponegoro Vol. 6 No. 1.

Kusumawati, Dwi and Dwi Ratmono. 2017. "Determinan Opini atas Laporan Keuangan Pemerintah Daerah di Indonesia.” Diponegoro Journal of Accounting Vol. 6.

Li, Liuchuang, Gaoliang T., Baolei Q. 2012. “Auditors' Unqualified Opinions on Internal Controls and Accrual Quality.” Nankai Business Review International Vol. 3 No. 4.

Munawar. 2016. "Pengaruh Jumlah Temuan Audit atas SPI dan Jumlah Temuan Audit atas Kepatuhan terhadap Opini atas Laporan Keuangan Pemerintah Kabupaten/Kota di Aceh.” Jurnal Magister Akuntansi, Pascasarjana Universitas Syiah Kuala. 
Ningsih, Sri. 2016. "The Antecedents of Non-Unqualified Opinions of Local Governments Financial Statements: A Study on Counties and Cities in East Java Province.” Asian Journal of Accounting Research.

Public Company Accounting Oversight Board. 2007. Auditing Standard No. 5 An Audit of Internal Control Over Financial Reporting That is Integrated with An Audit of Financial Statements and Related Independence Rule and Conforming Amendments.

Republik Indonesia. 1945. Undang-Undang Dasar 1945. Jakarta

Republik Indonesia. 2004. Undang-Undang Nomor 15 Tahun 2004 tentang Pemeriksaan Pengelolaan dan Tanggung Jawab Keuangan Negara. Lembaran Negara Republik Indonesia Tahun 2004 Nomor 66. Sekretariat Negara. Jakarta.

Republik Indonesia. 2008. Peraturan Pemerintah Nomor 60 Tahun 2008 tentang Sistem Pengendalian Intern Pemerintah. Lembaran Negara Republik Indonesia Tahun 2008 Nomor 127. Jakarta

Republik Indonesia. 2017a. Peraturan Badan Pemeriksa Keuangan Nomor 1 Tahun 2017 tentang Standar Pemeriksaan Keuangan Negara. Lembaran Negara Republik Indonesia Tahun 2017 Nomor 1. Jakarta

Republik Indonesia. 2017b. Peraturan Menteri Keuangan Republik Indonesia Nomor 14/PMK.09/2017 tentang Pedoman Penerapan, Penilaian, dan Reviu Pengendalian Intern atas Pelaporan Keuangan Pemerintah Pusat. Berita Negara Republik Indonesia Tahun 2017 Nomor 277. Jakarta

Safitri, N.L.K.S.A. dan Darsono. 2015. "Pengaruh Sistem Pengendalian Internal dan Temuan Kepatuhan terhadap Opini Audit pada Pemerintah Daerah.” Diponegoro Journal of Accounting Vol. 5.

Suwanda, Dadang. 2015. "Factors Affecting Quality of Local Government Financial Statements to Get Unqualified Opinion (WTP) of the Audit Board of the Republic of Indonesia (BPK)." Research Journal of Finance and Accounting Vol. 6 No. 4.

Widodo, P. and Sudarno. 2017. "Pengaruh Temuan Kelemahan Sistem Pengendalian Intern dan Temuan Ketidakpatuhan Terhadap Ketentuan Peraturan Perundang-Undangan Terhadap Opini BPK atas Laporan Keuangan Pemerintah Daerah.” Diponegoro Journal of Accounting Vol. 6 No. 1. 
The Indonesian Journal of Accounting Research - Sept, Vol. 23, No.3 , 2020

\section{Appendix 1}

The Level of Weakness of Internal Control System per Local Government

\begin{tabular}{|c|c|c|c|c|c|c|}
\hline No & Local Government & $\begin{array}{c}\text { Audit } \\
\text { Opinion }\end{array}$ & Inconsequential & $\begin{array}{l}\text { Significant } \\
\text { Deficiency }\end{array}$ & $\begin{array}{c}\text { Material } \\
\text { Weakness }\end{array}$ & $\begin{array}{c}\text { Number } \\
\text { of } \\
\text { Findings }\end{array}$ \\
\hline 1 & Kota Gorontalo & Unqualified & 1 & 11 & 1 & 13 \\
\hline 2 & $\begin{array}{l}\text { Kabupaten Banggai } \\
\text { Laut }\end{array}$ & Unqualified & 0 & 7 & 0 & 7 \\
\hline 3 & Kota Semarang & Unqualified & 3 & 5 & 0 & 8 \\
\hline 4 & $\begin{array}{l}\text { Kabupaten Ogan } \\
\text { Komering Ulu }\end{array}$ & Unqualified & 2 & 5 & 1 & 8 \\
\hline 5 & $\begin{array}{l}\text { Kota Tangerang } \\
\text { Selatan }\end{array}$ & Unqualified & 2 & 5 & 0 & 7 \\
\hline 6 & Kabupaten Mamasa & Unqualified & 0 & 4 & 0 & 4 \\
\hline 7 & Kabupaten Kapuas & Unqualified & 0 & 2 & 0 & 2 \\
\hline 8 & Kabupaten Pelalawan & Unqualified & 0 & 6 & 0 & 6 \\
\hline 9 & $\begin{array}{l}\text { Kabupaten Bangka } \\
\text { Tengah }\end{array}$ & Unqualified & 2 & 5 & 0 & 7 \\
\hline 10 & Kabupaten Asahan & Unqualified & 2 & 6 & 0 & 8 \\
\hline 11 & Kota Yogyakarta & Unqualified & 0 & 6 & 0 & 6 \\
\hline 12 & $\begin{array}{l}\text { Kabupaten Lombok } \\
\text { Barat }\end{array}$ & Unqualified & 0 & 4 & 0 & 4 \\
\hline 13 & Kabupaten Berau & Unqualified & 0 & 4 & 0 & 4 \\
\hline 14 & Kabupaten Lamandau & Unqualified & 0 & 4 & 0 & 4 \\
\hline 15 & $\begin{array}{l}\text { Kabupaten Kepulauan } \\
\text { Meranti }\end{array}$ & Unqualified & 1 & 2 & 0 & 3 \\
\hline 16 & Kabupaten Aceh Besar & Unqualified & 1 & 6 & 0 & 7 \\
\hline 17 & Kota Surabaya & Unqualified & 2 & 11 & 0 & 13 \\
\hline 18 & Kota Bogor & Unqualified & 0 & 4 & 0 & 4 \\
\hline \multicolumn{3}{|c|}{$\begin{array}{l}\text { Number of Findings for Unqualified } \\
\text { Opinion }\end{array}$} & 16 & 97 & 2 & 115 \\
\hline 19 & Kota Bandung & Qualified & 1 & 8 & 1 & 10 \\
\hline 20 & Kabupaten Tolitoli & Qualified & 0 & 5 & 2 & 7 \\
\hline 21 & $\begin{array}{l}\text { Kabupaten Bangka } \\
\text { Selatan }\end{array}$ & Qualified & 1 & 2 & 3 & 6 \\
\hline 22 & Kota Medan & Qualified & 0 & 4 & 3 & 7 \\
\hline 23 & Kabupaten Langkat & Qualified & 0 & 4 & 1 & 5 \\
\hline 24 & Kabupaten Katingan & Qualified & 1 & 8 & 1 & 10 \\
\hline
\end{tabular}




\begin{tabular}{|c|c|c|c|c|c|c|}
\hline No & Local Government & $\begin{array}{c}\text { Audit } \\
\text { Opinion }\end{array}$ & Inconsequential & $\begin{array}{l}\text { Significant } \\
\text { Deficiency }\end{array}$ & $\begin{array}{c}\text { Material } \\
\text { Weakness }\end{array}$ & $\begin{array}{c}\text { Number } \\
\text { of } \\
\text { Findings }\end{array}$ \\
\hline 25 & Kota Tarakan & Qualified & 0 & 5 & 2 & 7 \\
\hline 26 & Kabupaten Belu & Qualified & 3 & 3 & 1 & 7 \\
\hline 27 & Kabupaten Sampang & Qualified & 0 & 7 & 0 & 7 \\
\hline 28 & $\begin{array}{l}\text { Kabupaten } \\
\text { Pegunungan Arfak }\end{array}$ & Qualified & 0 & 7 & 2 & 9 \\
\hline 29 & $\begin{array}{l}\text { Kabupaten Mahakam } \\
\text { Ulu }\end{array}$ & Qualified & 0 & 7 & 3 & 10 \\
\hline 30 & Kabipaten Yalimo & Qualified & 0 & 8 & 3 & 11 \\
\hline 31 & Kota Bengkulu & Qualified & 0 & 6 & 1 & 7 \\
\hline 32 & Kabupaten Sambas & Qualified & 0 & 2 & 1 & 3 \\
\hline 33 & $\begin{array}{l}\text { Kabupaten Halmahera } \\
\text { Tengah }\end{array}$ & Qualified & 0 & 4 & 2 & 6 \\
\hline 34 & $\begin{array}{l}\text { Kota } \\
\text { Padangsidimpuan }\end{array}$ & Qualified & 1 & 6 & 1 & 8 \\
\hline 35 & $\begin{array}{l}\text { Kabupaten Maluku } \\
\text { Barat Daya }\end{array}$ & Qualified & 0 & 5 & 2 & 7 \\
\hline 36 & $\begin{array}{l}\text { Kabupaten Lampung } \\
\text { Timur }\end{array}$ & Qualified & 3 & 7 & 1 & 11 \\
\hline \multicolumn{3}{|c|}{$\begin{array}{l}\text { Number of Findings for Qualified } \\
\text { Opinion }\end{array}$} & 10 & 98 & 30 & 138 \\
\hline 37 & $\begin{array}{l}\text { Kabupaten Nias } \\
\text { Selatan }\end{array}$ & Disclaimer & 0 & 2 & 6 & 8 \\
\hline 38 & $\begin{array}{l}\text { Kabupaten Boven } \\
\text { Digoel }\end{array}$ & Disclaimer & 1 & 1 & 4 & 6 \\
\hline 39 & Kabupaten Puncak & Disclaimer & 0 & 4 & 3 & 7 \\
\hline 40 & Kabupaten Waropen & Disclaimer & 0 & 7 & 6 & 13 \\
\hline 41 & $\begin{array}{l}\text { Kabupaten } \\
\text { Mamberamo Raya }\end{array}$ & Disclaimer & 0 & 3 & 6 & 9 \\
\hline 42 & Kabupaten Tolikara & Disclaimer & 0 & 1 & 6 & 7 \\
\hline 43 & $\begin{array}{l}\text { Kabupaten Biak } \\
\text { Numfor }\end{array}$ & Disclaimer & 1 & 6 & 5 & 12 \\
\hline 44 & $\begin{array}{l}\text { Kabupaten } \\
\text { Simalungun }\end{array}$ & Disclaimer & 0 & 8 & 3 & 11 \\
\hline 45 & Kabupaten Sarmi & Disclaimer & 0 & 4 & 4 & 8 \\
\hline 46 & Kabupaten Mappi & Disclaimer & 0 & 4 & 2 & 6 \\
\hline 47 & Kabupaten Nias Barat & Disclaimer & 1 & 7 & 3 & 11 \\
\hline 48 & $\begin{array}{l}\text { Kabupaten Bolaang } \\
\text { Mongondow }\end{array}$ & Disclaimer & 0 & 5 & 2 & 7 \\
\hline 49 & $\begin{array}{l}\text { Kabupaten Morowali } \\
\text { Utara }\end{array}$ & Disclaimer & 1 & 7 & 3 & 11 \\
\hline
\end{tabular}


The Indonesian Journal of Accounting Research - Sept, Vol. 23, No.3 , 2020

\begin{tabular}{|c|l|l|c|c|c|r|}
\hline No & \multicolumn{1}{|c|}{ Local Government } & \multicolumn{1}{|c|}{$\begin{array}{c}\text { Audit } \\
\text { Opinion }\end{array}$} & Inconsequential & $\begin{array}{c}\text { Significant } \\
\text { Deficiency }\end{array}$ & $\begin{array}{c}\text { Material } \\
\text { Weakness }\end{array}$ & \multicolumn{1}{c|}{$\begin{array}{c}\text { Number } \\
\text { of } \\
\text { Findings }\end{array}$} \\
\hline 50 & $\begin{array}{l}\text { Kabupaten Buru } \\
\text { Selatan }\end{array}$ & Disclaimer & 0 & 4 & 4 & 8 \\
\hline 51 & $\begin{array}{l}\text { Kabupaten Kepulauan } \\
\text { Aru }\end{array}$ & Disclaimer & 0 & 6 & 4 & 10 \\
\hline 52 & $\begin{array}{l}\text { Kabupaten Seram } \\
\text { Bagian Barat }\end{array}$ & Disclaimer & 1 & 7 & 5 & 13 \\
\hline 53 & $\begin{array}{l}\text { Kabupaten } \\
\text { Mamberamo Tengah }\end{array}$ & Disclaimer & 0 & 7 & 4 & 11 \\
\hline 54 & $\begin{array}{l}\text { Kabupaten Dogiyai } \\
\text { Number of Findings for Disclaimer }\end{array}$ & Disclaimer & 1 & 4 & 3 & 8 \\
\hline \multicolumn{6}{|c|}{ OOpinion }
\end{tabular}

\section{Appendix 2}

The Effectiveness of Internal Control System per Local Government

\begin{tabular}{|c|l|l|c|}
\hline No & \multicolumn{1}{|c|}{ Local Government } & \multicolumn{1}{|c|}{$\begin{array}{c}\text { Effectiveness of Internal Control } \\
\text { System }\end{array}$} & $\begin{array}{c}\text { Audit } \\
\text { Opinion }\end{array}$ \\
\hline 1 & Kota Gorontalo & $\begin{array}{l}\text { Contains Material Weakness, Not } \\
\text { Pervasive }\end{array}$ & Unqualified \\
\hline 2 & Kabupaten Banggai Laut & Effective with Exceptions & Unqualified \\
\hline 3 & Kota Semarang & Effective with Exceptions & Unqualified \\
\hline 4 & Kabupaten Ogan Komering Ulu & $\begin{array}{l}\text { Contains Material Weakness, Not } \\
\text { Pervasive }\end{array}$ & Unqualified \\
\hline 5 & Kota Tangerang Selatan & Effective with Exceptions & Unqualified \\
\hline 6 & Kabupaten Mamasa & Effective with Exceptions & Unqualified \\
\hline 7 & Kabupaten Kapuas & Effective with Exceptions & Unqualified \\
\hline 8 & Kabupaten Pelalawan & Effective with Exceptions & Unqualified \\
\hline 9 & Kabupaten Bangka Tengah & Effective with Exceptions & Unqualified \\
\hline 10 & Kabupaten Asahan & Effective with Exceptions & Unqualified \\
\hline 11 & Kota Yogyakarta & Effective with Exceptions & Unqualified \\
\hline 12 & Kabupaten Lombok Barat & Effective with Exceptions & Unqualified \\
\hline 13 & Kabupaten Berau & Effective with Exceptions & Unqualified \\
\hline 14 & Kabupaten Lamandau & Effective with Exceptions & Unqualified \\
\hline 15 & Kabupaten Kepulauan Meranti & Effective with Exceptions & Unqualified \\
\hline 16 & Kabupaten Aceh Besar & Effective with Exceptions & Unqualified \\
\hline & & & \\
\hline
\end{tabular}




\begin{tabular}{|c|c|c|c|}
\hline No & Local Government & $\begin{array}{c}\text { Effectiveness of Internal Control } \\
\text { System }\end{array}$ & $\begin{array}{l}\text { Audit } \\
\text { Opinion }\end{array}$ \\
\hline 17 & Kota Surabaya & Effective with Exceptions & Unqualified \\
\hline 18 & Kota Bogor & Effective with Exceptions & Unqualified \\
\hline 19 & Kota Bandung & $\begin{array}{l}\text { Contains Material Weakness, Not } \\
\text { Pervasive }\end{array}$ & Qualified \\
\hline 20 & Kabupaten Tolitoli & $\begin{array}{l}\text { Contains Material Weakness, Not } \\
\text { Pervasive }\end{array}$ & Qualified \\
\hline 21 & Kabupaten Bangka Selatan & $\begin{array}{l}\text { Contains Material Weakness, Not } \\
\text { Pervasive }\end{array}$ & Qualified \\
\hline 22 & Kota Medan & $\begin{array}{l}\text { Contains Material Weakness, Not } \\
\text { Pervasive }\end{array}$ & Qualified \\
\hline 23 & Kabupaten Langkat & $\begin{array}{l}\text { Contains Material Weakness, Not } \\
\text { Pervasive }\end{array}$ & Qualified \\
\hline 24 & Kabupaten Katingan & $\begin{array}{l}\text { Contains Material Weakness, Not } \\
\text { Pervasive }\end{array}$ & Qualified \\
\hline 25 & Kota Tarakan & $\begin{array}{l}\text { Contains Material Weakness, Not } \\
\text { Pervasive }\end{array}$ & Qualified \\
\hline 26 & Kabupaten Belu & $\begin{array}{l}\text { Contains Material Weakness, Not } \\
\text { Pervasive }\end{array}$ & Qualified \\
\hline 27 & Kabupaten Sampang & $\begin{array}{l}\text { Contains Material Weakness, Not } \\
\text { Pervasive }\end{array}$ & Qualified \\
\hline 28 & Kabupaten Pegunungan Arfak & $\begin{array}{l}\text { Contains Material Weakness, Not } \\
\text { Pervasive }\end{array}$ & Qualified \\
\hline 29 & Kabupaten Mahakam Ulu & $\begin{array}{l}\text { Contains Material Weakness, Not } \\
\text { Pervasive }\end{array}$ & Qualified \\
\hline 30 & Kabupaten Yalimo & $\begin{array}{l}\text { Contains Material Weakness, Not } \\
\text { Pervasive }\end{array}$ & Qualified \\
\hline 31 & Kota Bengkulu & $\begin{array}{l}\text { Contains Material Weakness, Not } \\
\text { Pervasive }\end{array}$ & Qualified \\
\hline 32 & Kabupaten Sambas & $\begin{array}{l}\text { Contains Material Weakness, Not } \\
\text { Pervasive }\end{array}$ & Qualified \\
\hline 33 & Kabupaten Halmahera Tengah & $\begin{array}{l}\text { Contains Material Weakness, Not } \\
\text { Pervasive }\end{array}$ & Qualified \\
\hline 34 & Kota Padangsidimpuan & $\begin{array}{l}\text { Contains Material Weakness, Not } \\
\text { Pervasive }\end{array}$ & Qualified \\
\hline 35 & Kabupaten Maluku Barat Daya & $\begin{array}{l}\text { Contains Material Weakness, Not } \\
\text { Pervasive }\end{array}$ & Qualified \\
\hline 36 & Kabupaten Lampung Timur & $\begin{array}{l}\text { Contains Material Weakness, Not } \\
\text { Pervasive }\end{array}$ & Qualified \\
\hline 37 & Kabupaten Nias Selatan & $\begin{array}{l}\text { Contains Material Weakness, } \\
\text { Pervasive, Scope Limitation }\end{array}$ & Disclaimer \\
\hline 38 & Kabupaten Boven Digoel & $\begin{array}{l}\text { Contains } \quad \text { Material Weakness, } \\
\text { Pervasive, Scope Limitation }\end{array}$ & Disclaimer \\
\hline 39 & Kabupaten Puncak & $\begin{array}{l}\text { Contains Material Weakness, } \\
\text { Pervasive, Scope Limitation }\end{array}$ & Disclaimer \\
\hline
\end{tabular}


The Indonesian Journal of Accounting Research - Sept, Vol. 23, No.3 , 2020

\begin{tabular}{|c|c|c|c|}
\hline No & Local Government & $\begin{array}{c}\text { Effectiveness of Internal Control } \\
\text { System }\end{array}$ & $\begin{array}{l}\text { Audit } \\
\text { Opinion }\end{array}$ \\
\hline 40 & Kabupaten Waropen & $\begin{array}{l}\text { Contains Material Weakness, } \\
\text { Pervasive, Scope Limitation }\end{array}$ & Disclaimer \\
\hline 41 & Kabupaten Mamberamo Raya & $\begin{array}{l}\text { Contains Material Weakness, } \\
\text { Pervasive, Scope Limitation }\end{array}$ & Disclaimer \\
\hline 42 & Kabupaten Tolikara & $\begin{array}{l}\text { Contains Material Weakness, } \\
\text { Pervasive, Scope Limitation }\end{array}$ & Disclaimer \\
\hline 43 & Kabupaten Biak Numfor & $\begin{array}{l}\text { Contains Material Weakness, } \\
\text { Pervasive, Scope Limitation }\end{array}$ & Disclaimer \\
\hline 44 & Kabupaten Simalungun & $\begin{array}{l}\text { Contains Material Weakness, } \\
\text { Pervasive, Scope Limitation }\end{array}$ & Disclaimer \\
\hline 45 & Kabupaten Sarmi & $\begin{array}{l}\text { Contains Material Weakness, } \\
\text { Pervasive, Scope Limitation }\end{array}$ & Disclaimer \\
\hline 46 & Kabupaten Mappi & $\begin{array}{l}\text { Contains Material Weakness, } \\
\text { Pervasive, Scope Limitation }\end{array}$ & Disclaimer \\
\hline 47 & Kabupaten Nias Barat & $\begin{array}{l}\text { Contains Material Weakness, } \\
\text { Pervasive, Scope Limitation }\end{array}$ & Disclaimer \\
\hline 48 & Kabupaten Bolaang Mongondow & $\begin{array}{l}\text { Contains Material Weakness, } \\
\text { Pervasive, Scope Limitation }\end{array}$ & Disclaimer \\
\hline 49 & Kabupaten Morowali Utara & $\begin{array}{l}\text { Contains Material Weakness, } \\
\text { Pervasive, Scope Limitation }\end{array}$ & Disclaimer \\
\hline 50 & Kabupaten Buru Selatan & $\begin{array}{l}\text { Contains } \quad \text { Material Weakness, } \\
\text { Pervasive, Scope Limitation }\end{array}$ & Disclaimer \\
\hline 51 & Kabupaten Kepulauan Aru & $\begin{array}{l}\text { Contains Material Weakness, } \\
\text { Pervasive, Scope Limitation }\end{array}$ & Disclaimer \\
\hline 52 & Kabupaten Seram Bagian Barat & $\begin{array}{l}\text { Contains Material Weakness, } \\
\text { Pervasive, Scope Limitation }\end{array}$ & Disclaimer \\
\hline 53 & Kabupaten Mamberamo Tengah & $\begin{array}{l}\text { Contains Material Weakness, } \\
\text { Pervasive, Scope Limitation }\end{array}$ & Disclaimer \\
\hline 54 & Kabupaten Dogiyai & $\begin{array}{l}\text { Contains Material Weakness, } \\
\text { Pervasive, Scope Limitation }\end{array}$ & Disclaimer \\
\hline
\end{tabular}

